\title{
Perspectives on Reform of Financial Institutions
}

\author{
Paul R. Verkuil $\dagger$
}

Reform of financial institutions is a subject that simmers annually on many political back burners but rarely reaches the boiling point. Within one week during the month of August last summer, however, the Administration and Congress heated up the issue with detailed reports proposing major institutional reforms. This change in temperature did not go unnoticed: Spokesmen for the banking community acknowledged that this week could be "one of the most important in the recent history of the Nation's financial structure."1 While this does not necessarily mean that changes will occur, ${ }^{2}$ enough is now brewing to make appropriate a critical evaluation of the issues raised by these proposals.

The Department of the Treasury prepared the Administration report, ${ }^{3}$ which contained legislative proposals derived from an earlier report that the Hunt Commission ${ }^{4}$ had submitted to the Administration. Congressional reaction came in the form of a staff report by the House Committee on Banking and Currency, chaired by Congressman Wright Patman." In October 1973 the Administration submitted to the House and Senate comprehensive legislation embodying its earlier proposals entitled "The Financial Institutions Act of 1973." ${ }^{\prime}$ In No-

$\dagger$ Associate Professor of Law, University of North Carolina School of Law.

1. Banking, Sept. 1973, at 63 .

2. The political handicappers vary in their estimates of the likelihood of new legislation embodying these reforms, but the amount of industry discussion suggests that it is at least an open question. See, e.g., Am. Banker, Jan. 21, 1974, at 1, col. 2; Bus. Week, Nov. 3, 1973, at 83-84; BANkers Alonthly, Oct. 1973, at 20-28, 38-39.

3. Dep't of the Treasury, Recommendations for Change in the U.S. Financial System, Sept. 24, 1973 [hereinafter cited as Treasury Recommendations].

4. The Hunt Commission (named after its Chairman, retired Crown Zellerbach executive Reed O. Hunt) reported to the President on December 22, 1972. U.S. President's COMm'N ON Financial Structure Regulation, REPORT iii (1972) [hereinafter cited as HUNT COMM'N REPORT].

5. Staff of the House Comm. on Banking and Currency, 93d Cong., ist Sess., Financial Institutions: Reform and the Public INTEREST (Comm. Print 1973) [hereinafter cited as STAFF REPORT]. Occasionally the congressional proposals outlined in the STAFF REPORT will be designated herein as the "Patman proposals" to distinguish them from the "Administration proposals."

6. S.2591, 93d Cong., Ist Sess. (1973); H.R. 10990, 93d Cong., 1st Sess. (1973) (subtitled "A Bill to improve the efficiency and flexibility of the financial system of the United States in order to promote sound economic growth, including the provision of adequate funds for housing"). 
vember the Senate began hearings on this bill. ${ }^{7}$ By then, the House Committee on Banking and Currency had already completed hearings $^{8}$ on the proposals raised by its Staff Report. Specific legislation embodying the House proposals is being developed this spring and may be forthcoming by the opening of the 94th Congress.

This article will examine the professed goals of reform and evaluate the extent to which they are met by various legislative proposals. Of overriding importance to these legislative schemes is improvement of the flow of funds into the home mortgage market. ${ }^{9}$ The first section of this article will deal with that issue. The second section will examine bank trust departments and their impact upon the ability of financial institutions to compete effectively. While the Administration's proposals do not address this issue, this article will suggest that it is at the core of an overall approach to reform. The third section of this article will raise another issue that has gone unnoticed and is ignored by the Administration's proposals-the problem of institutional reform of the banking agencies themselves. An analysis of these three issues should provide a unified view of the major needs of financial institution reform. ${ }^{10}$

\section{Banking Competition and the Home Mortgage Market}

The Administration's legislative proposals are based upon the free market concepts articulated in the Hunt Commission Report and Treasury Recommendations. ${ }^{11}$ The essential idea is that, by removing interest rate and investment constraints on competition between commercial banks and thrift institutions, ${ }^{12}$ the federal government can

7. Hearings on Financial Structure and Regulation Before the Subcomm. on Financial Institutions of the Senate Comm. on Banking, Housing and Urban Affairs, 93d Cong., 1st Sess. (1973) [hereinafter cited as Senate Hearings].

8. Hearings on The Credit Crunch and Reform of Financial Institutions Before the House Comm. on Banking and Currency, 93d Cong., Ist Sess., pts. I \& II (1973) [hereinafter cited as Credit Crunch Hearings].

9. See President Nixon's Message to Congress, Aug. 2, 1973, reprinted in Treasury Recommendations, supra note 3 , at 1-3. The first sentence of that Message states, "Our country depends on a strong, efficient and flexible financial system to promote sound economic growth, including the provision of adequate funds for housing." Compare note 6 supra. See Robinson, The Hunt Commission Report: The Search for Politically Feasible Solutions to the Problem of Financial Structure, 27 J. Fis. 965, 971 (1972).

10. In researching this article I have conferred with, and read statements by, representatives of major interest groups, including the regulatory bodies themselves. I believe that whatever biases appear here (and undoubtedly some do) predate my current research.

11. See HUNT Comm'N REPort, supra note 4, at 17; Treasury Recommendations, supra note 3 , at 10 .

12. The term "bank" usually refers to commercial banks that receive demand deposits subject to check, make business, consumer, and personal loans, and provide 
promote the flow of new loanable funds to those institutions. To encourage the investment of these new funds in home mortgages, the Administration bill would give financial institutions a tax credit measured by the percentage of mortgage loans to total loans. ${ }^{13}$ The Patman proposals, as currently described in the Staff Report, ${ }^{14}$ suggest instead a direct constraint upon the market by requiring minimum investments in home mortgage loans. ${ }^{15}$ Both approaches, however, proceed from the premise that the present regulatory system is at fault. That system is therefore an appropriate place to begin evaluating the reform proposals.

\section{A. The Present Approaches to the Home Mortgage Problem}

Everyone realizes that mortgage money is tight today. It is either unavailable altogether or priced at an interest rate ${ }^{16}$ that makes it functionally unavailable to a vast portion of the population. ${ }^{17}$ The effect on home building is inexorable; housing starts have dropped dramatically. ${ }^{18}$ This situation seriously compromises the longstanding national policy "to provide a decent home and suitable living environment for every American family."19 The framers of the Housing and Urban Development Act of $1968^{20}$ predicted that, to meet announced goals, the housing industry would have to produce an average of 2.6

fiduciary services. Savings and loan associations and mutual savings banks are usually known as "thrift institutions." I will apply herein no absolute rule to limit the term bank or banking to the former context unless such steps are necessary to avoid confusion. The reader should remember, however, that the federal government does not charter mutual savings banks.

13. S.2591, 93d Cong., lst Sess., § 707 (1973). See Nixon-Hunt Proposals-Pro and Con, BANKers Monthly, Oct. 1973, at 20 (statement of William E. Simon). Some Hunt Commission members who preferred direct subsidies rejected this tax credit proposal. See Hunt CoMm'N Rerort, supra note 4, at 134 (dissent of W. Morton \& E. Malone).

14. STAFF REPORT, supra note 5, at 37-53.

15. Id. at 38 .

16. Interest rates on mortgage loans are running in excess of nine percent, and additional payments known as "points" (in effect prepaid interest due in a lump sum at closing) are frequently part of the loan package. See generally Treasury Recommendations, supra note 3 , at 2.

17. The staff of the House Committee on Banking and Currency has estimated, for example, that at an effective interest rate of nine percent (on a $\$ 20,000,30$-year mortgage), 60 percent of the families in the United States (those with annual incomes of less than $\$ 11,570$ ) are priced out of the housing market. See STAFF REPORT, supra note 5 , at $34-35$. This analysis assumes that families will allocate about 25 percent of their total income for housing.

18. See, e.g., HUD News, Feb. 6, 1974 (November, 1973, commitments for long-term residential mortgage Ioans were off by almost half compared to November, 1972); HUD Newsletter, Oct. 29, 1973 (housing starts for September, 1973, off 15 percent from August, 1973). But see Wall St. J., Mar. 19, 1974, at 1, col. 4 (starts in February, 1974 , rose 22 percent over prior month to a projected annual rate of 1.8 million units; this total is still below 1973 figures).

19. Housing Act of 1949, 42 U.S.C. $\$ 1441$ (1970).

20. Id. $\$ 1441(\mathrm{a})$. 
million new and rehabilitated units of housing annually over a tenyear period. ${ }^{21}$ Actual production in the four years since enactment has left a housing production "shortfall" of 3.2 million units. ${ }^{22}$ To some extent, at least, the success of bank regulatory policy, as well as related administrative programs, may be measured by the ability to meet this fundamental social goal. ${ }^{23}$

The historic regulatory response to the problem of providing funds for housing and mortgage markets has involved direct and indirect intervention. Federal repayment guarantees, provided by the Veterans' Administration (VA) and the Federal Housing Administration (FHA), encourage financial institutions to make higher risk home mortgage loans; ${ }^{24}$ and frequently the government itself directly enters the market and buys up mortgages from private institutions through the Federal and Government National Mortgage Associations. ${ }^{25}$ The government also seeks to foster the flow of deposits into institutions that make most of the home mortgage loans (the savings and loan associations and mutual savings banks) ${ }^{26}$ by establishing a deposit interest rate ceiling that favors those institutions. The federal banking agencies are empowered to set these ceilings, ${ }^{27}$ and have done so in such a manner as to shelter thrift institutions from deposit competition with commercial banks. ${ }^{28}$ In the early 1960's a favorable ceiling on

21. That figure includes annually 600,000 new and rehabilitated units allocated to low and moderate income families. STAFF REPORT, supra note 5, at 26.

22. Id. Of the overall shortfall, 1.1 million is in housing allocated to low and middle income families. These figures do not reflect mobile home production because mobile homes do not meet federally established space and construction standards. Id. One might well question, however, whether the 1968 housing goals are still appropriate in light of the changed character of population growth and the impact of environmental and energy considerations.

23. Another announced social goal, which will not be treated independently here, is to encourage investment in state and local bonds. See STAFF REPORT, supra note 5, at 1-48. And certainly one may suggest other goals of banking regulation, such as setting monetary policy, that must be evaluated separately.

24. See 38 U.S.C. $\$ \$ 1802-06,1810-17$ (1970); 12 U.S.C. $\$ \S 1709-15 \quad(1970)$.

25. See 12 U.S.C. $\$ \S 1716-23(1970)$. As of 1971, federal agencies held 8.7 percent of the loans financing one- to four-family residences. STAFF REPORT, supra note 5, at 37 , quoting The Savings ANd LoAN Fact Book of 1972.

26. As of 1971 , those institutions held 46.6 percent and 12.6 percent, respectively, of the outstanding loans financing one- to four-family residences. STAFF REPORT, supra note 5 , at 37 . From the asset side, as of the end of 1971, savings and loans and mutual savings banks held 69.3 percent and 43.1 percent, respectively, of their assets in the form of home mortgages. By comparison commercial banks held 8.5 percent of their assets in home mortgages. Id. at 86 (Table 17).

27. The Federal Home Loan Bank Board sets rates for savings and loan associations. 12 U.S.C. $\S 1425(1970)$. The Board of Governors of the Federal Reserve system limits the amount of interest that may be paid on time and savings deposits by members of the Federal Reserve system. Id. $\S 3716 ; 12$ C.F.R. $\S 217$ (1973). The FDIC sets rate ceilings for state nonmember banks. 12 U.S.C. $\$ 1828(\mathrm{~g})$ (1970). Since each of the three banking agencies consults the others prior to issuing a regulation, there is normally no difference among the rate ceilings. This coordination of function will be assumed throughout this article when rate ceilings are discussed.

28. See 12 C.F.R. $\$ 217$ (1973) (Regulation Q). 
time deposits relative to market rates encouraged retention of funds in the favored institutions, and funds for mortgage loans were consequently plentiful. ${ }^{29}$ But in years of tight money-1966, 1969, and 1974-the Federal Reserve Board (FRB) has pursued a restrictive monetary policy as a means of controlling inflation. ${ }^{30}$ The result has been money market interest rates significantly higher than the interest ceiling which depository institutions (either thrifts or commercial banks) were permitted to offer. The power to limit rates under Regulation $Q$ consequently became ineffective as a means of ensuring a deposit flow to thrift institutions, ${ }^{31}$ and in fact had a perverse effect on such deposit flows. When money market rates also exceeded what could permissibly have been paid by depository institutions, there was a flight of funds from savings accounts into higher yielding money market instruments (such as Treasury Bills and market securities), a phenomenon analysts labeled "disintermediation." 32 While all financial institutions are disabled by interest ceilings which act to prevent intermarket competition for funds, thrift institutions face a more serious liquidity crisis than commercial banks because of their heavy investment in long-term mortgage loans and because of statutory prohibitions on lending. ${ }^{33}$ This crisis produces a dramatic decline in net loanable funds by thrifts and, since mortgages are their main investment, a serious constriction on the amount of home mortgage money available. ${ }^{34}$ Disintermediation can seemingly occur overnight, whenever the FRB tightens monetary policy. When the FRB tightened monetary policy in 1966, for example, net loanable funds of savings and loan associations declined sharply by 30 percent from the prior year. $^{35}$

To some extent the federal banking agencies have attempted to

29. See generally S. Cohan, The Regulation of Interest Rate Ceilings, FDIC Working Paper 73-10 (1973).

30. See Knight, Comments on the Hunt Commission Report, FRB K.C. MonthLY Rev., Sept.-Oct. 1972, at 3-4.

31. Id. See also Robinson, supra note 9, at 770 .

32. See generally P. SAmuelson, Economics: AN INTroductory ANALYsis 303-04 (8th ed. 1970).

33. Thrifts are said to be in the posture of "borrowing short and lending long" because of regulatory constraints that limit investments principally to real estate loans. In fact over 85 percent of all assets of thrifts are invested in home mortgage loans. Knight, supra note 30 , at 5 . The remainder of investments for federal savings and loan associations are in home modernization and repair, mobile home, educational, and saving account loans, all of which may also be unattractive in a tight money situation. Id. at 6 .

34. Tight money policy also serves to extend the length of lower interest mortgage loan commitments, which further restricts the amount of loanable funds available to thrifts. Since 1966, for instance, the average life of a mortgage loan has increased from six to eight years to about 14 years. Id. at 6 n.4.

35. The decline was from $\$ 24.5$ billion in 1965 to $\$ 17.4$ billion in 1966 . Id. at 6 . 
overcome this cyclical availability of mortgage loans by raising interest rate ceilings (especially on long-term deposits) under Regulation $Q .{ }^{36}$ This approach has not insured a steady flow of funds into the home mortgage market. ${ }^{37}$ Reforms to free financial institutions from regulatory constraints that supposedly prevent them from reacting effectively to conditions in the general money market have therefore been suggested.

\section{B. A Critique of Proposed Reforms}

The proposed Financial Institutions Act and the reports that support it conclude that the liquidity ills currently confronting thrift institutions (and the home mortgage market they serve) can best be overcome by massive de-regulation designed to revive competitive forces in the market place. The Administration's de-regulation proposal consists of several connected steps. ${ }^{38}$ One is a general phaseout of interest ceilings. The ceilings contained in Regulation $\mathbf{Q}$ are to be phased out over a five-and-one-half-year transition period and the FHA and VA ceilings are to be removed immediately. ${ }^{39}$ However, the Hunt Commission's recommended imposition of a variable interest rate on mortgages was not included in the Act. ${ }^{40}$

Coupled with the phaseout of ceilings are several changes designed to make thrift institutions and credit unions in many respects like

36. One way the banks were able to fight this outflow of funds was by the use of long-term four-year certificates of deposit which provide for higher interest rates. The FRB approved so-called "wildcard certificates" in \$1,000 denominations which were unrestricted as to the rate that could be paid. See Credit Crunch Hearings, supra note 8, at 59, 62-63 (statement of Savings \& Loan League Chairman, Legis. Comm., Tom B. Scott, Jr.). But the thrift institutions recently prevailed upon Congress to require banking agencies to establish an interest rate ceiling on those certificates. Act of Oct. 15, 1973, Pub. L. No. 93-123, 87 Stat. 449. The current ceilings are $71 / 4$ percent for commercial banks and $71 / 2$ percent for thrifts. There is no ceiling on certificates over $\$ 100,000$. Fed. Res. BuLL., Mar. 1974, at Al0.

37. See STAFF REPORT, supra note 5, at 65-80.

38. The President has urged that these steps be enacted as a package in order to achieve the desired results. Treasury Recommendations, supra note 3, at 3. See BANKING, supra note 1 .

39. S.2591, 93d Cong., 1st Sess., \$ $\$ 101.06$ (1973) (Title I). This title eliminates the interest rate ceiling and the differential in maximum allowable interest rates between thrifts and commercial banks in four steps over a transition period designed to minimize market disruption. The title also allows for payment of interest on certain types of demand deposit accounts known as negotiable order of withdrawal (N.O.W.) accounts. The bill does not permit, however, the long forbidden payment of interest on simple demand deposits or checking accounts. See HUNT Comm'N REPoRT, supra note 4, at 27; Treasury Recommendations, supra note 3 , at 6 . See generally $\mathbf{P}$. SAMUELSON, supra note 32, at 302-03. N.O.W. accounts are currently permitted in two states-Massachusetts and New Hampshire. See Consumers Sav. Bank v. Commissioner of Banks, 282 N.E.2d 416 (Mass. 1972). In addition, several states will permit checking accounts to bear interest soon. See Allen, The Hunt Commission Report, Bus. LAw., Jan. 1974, at $499,511$.

40. See Treasury Recommendations, supra note 3 , at 32 . 
commercial banks. ${ }^{41}$ Thrifts may offer third party payment services (such as checking accounts and credit cards) and consumer and education loans. The restrictions on investment in real estate loans are lifted. ${ }^{42}$ In return for these expanded competitive powers, thrifts are deprived of tax credits for reserves of mortgages, which are currently denied commercial banks, in an attempt to achieve "tax neutrality" for all financial institutions. ${ }^{43}$ The proposed tax credit is equal to a percentage of the interest earned in residential mortgage holdings, and it is available equally to all financial institutions. ${ }^{44}$

The Patman proposals, like those of the Administration, are based upon the assumption that expansion of the credit base to include all financial institutions is a desirable first step to infuse funds into the home mortgage market. They, however, do not rely on the market alone to satisfy the goals of national policy. Once all financial institutions are made functionally similar, they will be required to invest a portion of their assets (measured by their asset growth rate for the previous year) ${ }^{45}$ in the home mortgage market. To insure this level of contribution, any shortfall in required mortgage investments would translate into a mandatory deposit of the shortfall amount in the federal reserve bank for direct mortgage investment by that institution. ${ }^{40}$ The goal of this requirement is to give financial institutions every incentive to involve themselves directly in the home mortgage market at least to the extent of their annual asset growth.

The Patman proposals, unlike those of the Administration, do not abolish interest rate ceilings. They retain the FHA and VA ceilings

41. S.2591, 93d Cong., 1st Sess., \$§ 201-02 (1973) (Title II).

42. Thrifts are, however, still prohibited from making business loans, which are by far the largest category of commercial bank loans. See note 78 \& pp. 1360-61 infra.

43. S.2591, 93d Cong., 1st Sess., \$\$ 701-09 (1973) (Title VII). See Senate Hearings, supra note 7 , at 33 (statement of William E. Simon); Treasury Recommendations, supra note 3 , at 6-7.

44. The tax credit is designed to induce investment in residential mortgages by setting various incentive levels. Thus, for institutions with 70 percent of their assets in mortgage loans, a credit equal to 3.5 percent of mortgage income is allowed. For each percent below 70 percent, the credit is reduced by one-thirtieth. S.2591, 93d Cong., lst Sess., $\$ 707$ (1973). The Administration estimates that this provision will cost the Treasury $\$ 180$ million more (or $\$ 712$ million) than the current tax benefit provisions for thrift institutions. Based on current mortgage holdings, thrifts would receive most of the new tax credit (commercial banks hold an average of about 8 percent of their assets in residential mortgages). See Senate Hearings, supra note 7, at 34-35 (statement of William E. Simon). This tax credit has been criticized as inadequate to encourage mortgage investment. See Bus. WEEK, Nov. 3, 1973, at 83. But see Kane, Taxation of Savings \& Loans and Commercial Banks, FED. HOME. LoAN BANK BD. J., July 1973, at 10.

45. StafF REPORT, supra note 5, at 3, 38. This limitation is designed to avoid serious disruption for commercial banks, which presently are not significant home mortgage lenders.

46. Id. 
in order to prevent lenders from pricing such mortgage loans well above the conventional rate and thereby restrict the ability of some lower income families to purchase homes. ${ }^{47}$ For similar reasons the Patman proposals reject the variable interest rate. ${ }^{48}$

These two proposals approach the question of banking reform from two different directions. The Administration, despite some statements to the contrary, seems more concerned with the efficiencies that will supposedly arise as a result of the operation of the competitive market. ${ }^{49}$ The Patman proposals, however, while not disavowing efficiency (in the form of more bank and thrift competition), are more concerned with questions of equity and redistribution. These approaches, of course, represent the classic tension in regulatory decisionmaking. Once identified, this tension helps to explain the reaction of many who will be most directly affected by the legislation.

\section{Industry Reaction}

As expected, industry and regulators have widely divergent views on the proposed reforms. The thrift institutions, which are to gain many of the powers of commercial banks under both proposals, have indicated that the loss of favored treatment (interest ceilings and tax advantages) is too high a price to pay for equality. ${ }^{50}$ Thrift spokesmen have suggested a compromise which would grant them the benefits of the competitive proposals (new investment and third party payment powers) but retain the existing protections (such as the tax-free bad debt reserve for mortgage loans and the interest rate differentials). ${ }^{51}$ At the heart of the objections to the Administration's proposals is the fear that open competition by thrifts or small banks with large commercial banks would lead to market dominance by those larger institutions. ${ }^{52}$

\section{Id, at 30 .}

48. The concern here is that home owners are less able than lenders to absorb the increased costs of higher interest rates during tight money periods. Id. at 30-31.

49. Deputy Treasury Secretary Simon, speaking for the Administration, outlined six goals of the President's recommendations. The first was "to create a more efficient financial system," the second was "to have our financial system serve all the needs of the community," and the fifth was to provide "a more stable and constant flow of funds into housing ...." Senate Hearings, supra note 7, at 23.

50. See Credit Crunch Hearings, supra note 8, at 23-57 (statement of Raleigh W. Greene, President, Nat'l League of Insured Sav. Ass'ns).

51. See, e.g., statement of William L. Reynolds, Executive Director, Nat'l League of Insured Sav. Ass'ns, quoted in Bankers Monthly, Oct. 1973, at 27-28.

52. See, e.g., statement of Howard Bell, Executive Director, Independent Bankers Ass'n, quoted in BANkers MoNTHLY, Oct. 1973, at 22-23. Mr. Bell argued:

One effect of this proposal would be greater banking concentration. The large financial institutions, those with the greatest capacity to establish branches, would grow larger. The small would grow smaller or become branches of the 
Perhaps not surprisingly, large commercial banks have generally supported open competition among financial institutions. ${ }^{53}$ The American Bankers Association (ABA) has called the Administration's proposals "the most important potential banking legislation in the last 40 years." ${ }^{4} 4$ As of this date, the $\mathrm{ABA}$ has been lobbying for the enactment of the Financial Institutions Act of 1973, although objections of its smaller bank members have led the ABA to oppose removal of Regulation $Q$ interest rate ceilings. ${ }^{55}$

The federal agencies which share jurisdiction over financial institutions (the FRB, Comptroller of the Currency, and the Federal Deposit Insurance Corporation (FDIC)) have also generally favored the Administration's proposals. The Comptroller has enthusiastically endorsed the bill and concluded that if adopted in full it would open "an era of challenge and opportunity for all." 56 FRB Chairman Arthur Burns favors proposals to allow thrift institutions to compete in other lending markets, such as the market for consumer loans, so as to avoid the asymmetry and disintermediation caused by lending long and borrowing short.57 Burns has also encouraged use of the variable interest rate. ${ }^{58}$ The FDIC favors the two basic objectives of reform proposed by the Administration (and concurred in by the Patman proposals): removal of deposit rate ceilings, and expansion of asset and deposit powers of thrifts. ${ }^{59}$

Other federal agencies without direct supervisory responsibility over financial institutions have also commented on the proposed reforms. The Securities and Exchange Commission stressed the competitive threat to the marketplace posed by the huge financial re-

larger. Competition, the public's one real protection in our economy, would be eroded or destroyed. So would consumer and small business options because loan sources, especially those available to such groups, would be fewer, with the higher rates and less favorable terms such a market brings. In addition, resources would be drained from many areas, particularly rural districts-where country banks invest locally, large banks tend to invest in national or international market places to secure the highest terms.

53. See Credit Crunch Hearings, supra note 8, at 769-78 (statement of Am. Bankers Ass'n President Eugene H. Adams).

54. Statement of Eugene H. Adams, Chairman, Governing Council, Am. Bankers Ass'n, quoted in Bankers Monthly, Oct. 1973, at 22. See Am. Bankers Ass'n, Summary and Interpretive Analysis of the [Hunt Commission] Report, Mar. 1972.

55. See Bus. WeEk, Nov. 3, 1973, at 83. It has been suggested that one of the concerns of small banks is that removal of interest rate ceilings will reduce their profits since they operate in sheltered market areas where deposit flows are unaffected by interest rate competition. See S. Cohan, supra note 29.

56. Statement of James E. Smith, quoted in Bankers Monrhly, Oct. 1973, at 28. See Credit Crunch Hearings, supra note 8, at 384-86 (statement of the Comptroller of the Currency, James E. Smith).

57. See Credit Crunch Hearings, supra note 8, at 313-22.

58. Id. at 321 .

59. See id. at 392 (statement of FDIC Chairman Frank Wille). 
sources of commercial banks; ${ }^{60}$ but the Justice Department has generally discounted that danger by suggesting that remedies under the antitrust laws are adequate to deal with the problem of concentration. ${ }^{61}$ The New York Superintendent of Banks pointed out that, even without new legislation, recent action has drastically reduced the protection that Regulation $Q$ provides thrift institutions. ${ }^{02}$ Finally, public interest groups have tended to doubt the likelihood that the Administration's proposals are adequate to ensure the public objective of providing additional funds for the home mortgage market. ${ }^{83}$

\section{A Critical Assessment}

Most agree that the present scheme of regulation is less than optimal, since it was inspired by the insolvency fears of the Depression era and has not since been systematically reexamined. ${ }^{\text {if }}$ Today the focus on bank solvency as the rationale for regulation is less relevant than other goals, such as the need to maximize efficient allocation of available funds for priority purposes. The Administration and Patman proposals, therefore, both view the current regulation as excessive and counterproductive. The proposals also profess agreement on the importance of setting aside additional funds for housing; but they disagree substantially on methods of implementing that goal.

If the Administration is correct that free competition (with moderate tax incentives) will achieve stated home mortgage market goals, imposition of the mandatory controls contained in the Patman proposals is unnecessary and inadvisable. But for two basic reasons the evidence in support of the free market solution must be closely assessed before regulatory policy is revised. First, if the competitive model does prove inadequate to achieve desired goals, new regulatory issues will have to be confronted, including of course the politically sensitive issue of direct housing subsidies. ${ }^{65}$ Second, resort to competi-

60. The SEC is concerned about the impact of commercial bank entry (either directly or through deposit rate competition) into the securities markets. Id. at 520.26 (statement of SEC Chairman Ray Garrett, Jr.).

61. Id. at 526-38 (statement of Donald I. Baker, Director of Policy Planning, Antitrust Div., Dep't of Justice).

62. Harry W. Albright, Jr., Address to Savings Banks Ass'n of New York State, Nov. 12, 1973, at 3.6 [hereinafter Albright Address]. Compare Credit Crunch Hearings, supra note 8, at 463 (statement of Prof. Fairfax Leary).

63. See, e.g., Credit Crunch Hearings, supra note 8, at 458.95 (statement of Ralph Nader).

64. See, e.g., id. at 473 (statement of Ralph Nader); Treasury Recommendations, supra note 3 , at 1 .

65. The stigma that our society places upon direct payments, e.g., welfare, should not be ignored. In regulatory matters, there is a tradition of full cost pricing that encourages the (direct) beneficiaries to bear the burden. Variations from this regulatory 
tion in the banking industry may have other deleterious social effects if the market structure of that industry demonstrates the presence of significant economies of scale. In the presence of scale economies, the competitive market might soon be supplanted by a concentrated one, which would, in turn, present regulatory problems of perhaps a different nature.

As to the first issue, ${ }^{b 6}$ the evidence in favor of competition as a solution to mortgage money problems is thin indeed. There is an inevitable conflict between competition among lenders and subsidization (of home mortgages) by lenders in banking. One contemplates market freedom, the other market control. But the Administration's proposals proceed on the assumption that banking competition will lead to asset diversification which will allow thrift institutions to compete for loanable mortgage funds in tight money periods. ${ }^{67}$ Thrifts structured like commercial banks, however, may behave like commercial banks, and available data tend to show that the diversified lenders (i.e., commercial banks) have, except for the most recent periods, contributed most to the instability of home mortgage lending during tight money periods. ${ }^{68}$ If the past is any guide, permitting diversification of the asset portfolios of thrift institutions will not improve the flow of funds into the home mortgage market. ${ }^{69}$

Moreover, the Administration's own data on this point are not convincing. Its only empirical evidence comes from a study commissioned by the Department of Housing and Urban Development which simulated the impact of the Hunt Commission recommendations on the economy of the 1960 's. $^{70}$ The study concluded, somewhat equivocally, that the amount of mortgage money would increase or decrease only slightly. ${ }^{11}$

The Administration's proposals rely heavily upon a tax credit to offset the loss of tax advantages to the thrifts. Currently, thrifts enjoy

practice may be defended precisely because they achieve certain social goals through internal subsidization that might not be possible by direct legislative intervention. Compare Posner, Taxation by Regulation, 2 BELL J. EcoN. MGT. ScI. 22 (1971).

66. The market concentration issue is discussed at pp. 1361-66 infra.

67. See Hunt Comm'N Report, supra note 4, at 78-79.

68. The FDIC has heavily researched this question. See R. Boorman \& M. Peterson, An Evaltuation of the Recommendations of the Hunt Commission Related to Housing Expenditures and the Mortgage Market, FDIC Working Paper 72-7, at 30 (1972); Boorman \& Peterson, The Hunt Commission and the Mortgage Market: An Appraisal, 3 J. BANK RESEARCH 155, 164 (1972); Boorman \& Peterson, The Instability of Savings Flows and Mortgage Lending by Financial Intermediaries, 40 S. EcoN. J. 297 (1973).

69. Id.

70. This was prepared by two Princeton University economists, Roy Fain and Dwight Jaffee, pursuant to HUD contract H1781, April 1972. Treasury Recommendations, supra note 3 , at 30,41 .

71. Id. 
a tax advantage, not given to commercial banks, that allows them to make tax deductible contributions to bad debt reserves. Such contributions consistently exceed actual default experience. ${ }^{72}$ The proposals will replace that incentive with a general tax credit, which will be available to all financial institutions, for interest earned on residential mortgage loans. ${ }^{73}$ The Administration expects that the current tax subsidy, amounting to $\$ 545$ million, in the form of tax-free contributions to bad debt reserves, will be replaced by a tax credit of at least the same amount. This will mean, therefore, that thrifts will receive a lower overall subsidy, since a share of the subsidy will be enjoyed by commercial banks. ${ }^{74}$ As a consequence, the incentives for thrifts to serve the home mortgage market will diminish and, at the same time, the incentives for commercial banks to switch from corporate and commercial loans to housing may be insufficient to make up the difference. Thrifts will be permitted, for instance, to invest in consumer loans and bonds; the net result might well be a substantial outflow of funds from the home mortgage market.75 Commercial banks are unlikely to make up any such deficit, let alone add to their current total commitments. ${ }^{76}$ If home mortgage investment has such a high social priority, the Administration's voluntary tax incentive program may be seen more to jeopardize than vindicate that policy.

In this context, the Patman proposals offer a viable, but not costless, alternative. The Patman proposals require all financial institutions to invest annually in home mortgages to the extent of their overall asset growth for the year. While this approach compromises the free market concepts supported by the Administration, it may ensure compliance with the desired social goals expressed by Congress over the last 40 years. For example, if the Patman proposals had been law, there would have been an additional $\$ 15.6$ billion for the home mortgage market in the period from 1960 to $1970 .{ }^{77}$ Moreover, the proposals do

72. Id. To obtain the maximum deduction, 82 percent of the thrifts' assets must be eligible assets (residential mortgages); if less than 60 percent of the total assets are eligible, the bad debt reserve deduction is not available. Id. at 27.

73. See p. 1355 supra.

74. See id.; Treasury Recommendations, supra note 3, at 29. This is the judgment of several knowledgeable observers. See, e.g., Bus. WEEK, Nov. 3, 1973, at 83-84.

75. This conclusion is based on a potential $\$ 63$ billion reduction of the $\$ 340$ billion currently estimated to be invested in the home mortgage market. Credit Crunch Hearings, supra note 8, at 461 (statement of Prof. Fairfax Leary).

76. However, it should be noted that real estate loans reveal lower operating costs in large scale operations than do other types of commercial bank loan activity. See note 89 infra. While this fact may play a role in the bank's decision to invest in home mortgages, the long-term nature of the commitment may offset it.

77. STAFF RePORT, supra note 5, at 38 . 
not ignore the goals of competition; in some respects they go further than the Administration's de-regulation scheme. ${ }^{78}$ On the other hand, once a decision is made mandatorily to allocate funds for priority purposes, inevitable questions of inefficiency and compromise with other goals arise which could well generate other problems in the future. ${ }^{79}$

Both proposals accept the desirability of a competitive banking industry, and this raises a second inquiry not directly addressed in either proposal. If in fact the underlying competitive model is unsound, or even dubious, the ultimate impact of these reforms may well require greater government control. It seems advisable to consider the validity of the competitive model as a major premise by evaluating the extent to which scale economies might ultimately frustrate the goals of competition.

\section{Competition, Economies of Scale, and Regulatory Policy}

Federal savings and loan associations were created by a beneficent Congress some 40 years ago to foster home ownership. ${ }^{80}$ Now to convert these institutions into, in effect, commercial banks involves a serious change in role. ${ }^{81}$ In terms of present priorities, this conversion would seem justified only if competition would not frustrate those social goals that led to the congressional support of thrifts. If, on the other hand, the existence of scale economies suggests that free competition is only a way station on the road to concentration, and if the resulting large firms (which would presumably be the larger commercial banks) would be less inclined to serve those social goals, regulation would have to begin anew to achieve the goals currently, and perhaps inefficiently, met under the existing system.

The literature on economies of scale in commercial banking is

78. The Patman proposals go beyond those of the Administration in that they would allow payment of interest on demand deposits, a free market alternative rejected by the Administration. See id. at 89.91; HUNT CoMm'N REPORT, supra note 4, at 27-29; Treasury Recommendations, supra note 3 , at 6.8. See also Eisenbeis, The Hunt Commission and Interest Payments on Demand Deposits, MAG. BANK AD., Jan. 1973, at 27. In addition the Patman proposals would allow thrifts to compete with commercial banks for business loans. See STAFF REPORT, supra note $\mathbf{5}$, at 89 . Business loans constitute the largest lending categories for commercial banks. For example, the total loans of commercial banks reported as of June 30,1973 , amounted to $\$ 426$ billion. Of that total $\$ 224$ billion fell into the category of business loans. FED. REs. BuLL., Mar. 1974 , at A22.

79. In this context, it should be noted that different ways of achieving the desired fund flows, such as subsidies on the borrower side of the market, are worthy of consideration.

80. See Federal Home Loan Bank Act of 1932, 12 U.S.C. \$\$ 1421.49 (1970); STAFF REPORT, supra note 5 , at 31 .

81. Some thrifts have already been given powers inconsistent with their traditional roles to stimulate deposit inflows. Treasury Recommendations, supra note 3, at 16-17. 
abundant ${ }^{82}$ and often contradictory. While some suggest that scale economies do exist, ${ }^{83}$ others contend that efficiencies of banking operation are not largely a function of size. ${ }^{84}$ One of the most elaborate studies on the subject (an examination of the banks in the Kansas City Reserve District) concluded that average costs diminished until an optimum bank size of $\$ 300$ million in assets was reached. ${ }^{85}$ This asset figure is about 12 times the asset size of the average bank in the United States. ${ }^{86}$ But as of December 31, 1972, 261 commercial banks, 95 savings \& loans and 78 mutual savings banks exceeded $\$ 300$ million in assets. ${ }^{87}$ The average costs of banks of optimal size were figured to be 30 percent lower than the costs of the then existing banks in the Kansas City Reserve District. ${ }^{88}$ Detailed studies have been completed at the FDIC which conclude that scale economies are largely limited to the operations of a single banking office (and the customers it serves). ${ }^{89}$ These studies suggest that large single unit commercial banks can compete effectively with branch banking institutions, but they recognize that unrestricted branching can lead to excessive market power in the hands of the branching bank..$^{00}$ Of course, the power

82. See, e.g., D. AlhadefF, Monopoly and Competition in Banking (1954); L. Gramley, A Study of SCAle Economics in Banking (1962); P. SMith, Economics of Financial Institutions and MARKets (1971). See also Bengston, The Optimal Banking Structure: Theory and Evidence, 3 J. BANK RESEARCH 220 (1973).

83. See Wu \& Connell, Merger Myopia: An Economic View of Supreme Court Decisions on Bank Mergers, 59 VA. L. REV. 860, 878-81 (1973). See also Bengston, Cast of Operations and Economies of Scale in Savings and Loan Associations, in STUDY OF THE SAvings AND LOAN INDUSTRY 677 (I. Friend ed. 1969).

84. Bengston, Economies of Scale and Marginal Costs in Banking Operations, 2 NaT'L BaNKING Rev. 507, 541 (1965).

85. Greenbaum, $A$ Study of Bank Costs, 4 Nat'l Banking Rev. 415 (1967); Greenbaum, Competition and Efficiency in the Banking System-Empirical Research and its Policy Implications, $75 \mathrm{~J}$. PoL. EcoN. 461 (1967). Mr. Greenbaum concludes that reduction in the number of banks to 100 would produce cost savings of about $\$ 1$ billion. Id. at 473-74.

86. See Greenbaum, A Study of Bank Costs, supra note 85, at 434; Wu \&: Connell, supra note 83 , at 879 .

87. See Am. Banker, Feb. 13, 1973, at 105-10; Feb. 23, 1973, at 12-13; Jan. 31, 1973 , at 12-13.

88. See Greenbaum, $A$ Study of Bank Costs, supra note 85, at 434.

89. See W. Longbrake, Productive Efficiency in Commercial Banking: The Impact of Bank Organizational Structure and Bank Size on the Cost of Demand Deposit Services, FDIC Working Paper 72-10 (1972). The FDIC has, however, opposed bank mergers in the courts by seeking to refute arguments asserting scale economies. See, e.g., Brief for FDIC as Amicus Curiae at 17, United States v. First Nat'l Bancorporation, Inc., 410 U.S. 577 (1973). FDIC analysis of the operating costs of a nationwide sampling of 972 banks revealed some economies of scale in certain commercial bank services and no significant ones in others (demand deposits, time deposits, installment loan functions, and safety deposit box services). Those services with scale economies showed for a 10 percent increase in output the following increased costs: business loans, 8.761 percent, securities and investments, 8.245 percent, and real estate loans 8.139 percent. Id. at 18 .

90. See Gilbert \& Longbrake, The Effects of Branching by Financial Institutions on Competition, Productive Efficiency and Stability: An Examination of the Evidence, 4 J. Bank Research 154, 298, 304 (1973-74) (also published as FDIC Working Paper 74-1). 
to permit branching is normally held by state banking agencies which themselves add another variable to regulatory policy. ${ }^{91}$ Indeed, recent state laws are acting to discourage banking concentration by placing a maximum deposit limitation upon bank and bank holding companies operating in the state. ${ }^{92}$

Taken as a whole these studies suggest that banking is not free from economic pressures which may lead to industry concentration. And viewed as an original proposition, it would seem that economies of scale should exist in banking. The major indicia of scale economies (specialization of labor, indivisibilities, and risk reduction) are present in the banking industry, ${ }^{93}$ and while some of these economies can be realized at the unit level, as the FDIC studies suggest, others (such as investment in computer equipment ${ }^{94}$ and stabilization of lending risks over a large number of accounts) would not appear to be exhausted at that level.95 The risk factor with respect to total with-

91. State branching practices vary dramatically. The FRB has determined that 20 states permit statewide branching, 16 limited branching, and 15 permit only unit (single) banks. The states in which banking is highly concentrated tend to be those with statewide branching practices. See S. Talley, The Impact of Holding Company Acquisitions on Aggregate Concentration in Banking, Mar. 1973, at 12, 21, 23 (FRB Publication). In New York, statewide branching will be permitted after January 1, 1976, N.Y. BANKing LAw \$ 105 (McKinney Supp. 1973-74), and savings banks are already discussing the potential impact that increased competition will have on smaller banks. See Albright Address, supra note 62, at 15-16. As a matter of federal banking policy, state laws generally control the branching policies of national banks, although the Federal Home Loan Bank Board has the power to establish branching guidelines for federal associations. See 12 U.S.C. § 1437(a) (1970); Allen, The Hunt Commission Report, 29 Bus. LAw. 497, 515 (1974).

92. See, e.g., IowA CODE ANN. \$ 524.1802 (West Supp. 1974-75) (no bank holding company may control banks with more than 8 percent of the total state bank deposits): N.H. REv. STAT. ANN. $\$ 384-B: 3$ (1968) (holding companies limited to banks with 20 percent of state bank deposits); N.J. STAT. ANN. \$ 17:9A-345 (West Supp. 1973-74) (same). See also Am. Banker, Mar. 12, 1974, at 1, col. I (discussing proposed Texas constitutional amendment to limit holding companies to 8 percent of state's total deposits).

93. See Wu \& Connell, supra note 83 , at 878.

94. Economies of scale based on the provision of computer services are of three basic types. First, as a general rule larger computer systems provide better performance at a lesser price than smaller computer systems. Second, reliability and availability are critical to a bank's computer system; if a bank's computer is "down" for any significant length of time, the bank may be virtually unable to function. In a very large facility there will typically be several computers of the same or similar types. If one computer malfunctions, any critical applications that would ordinarily be performed on it can be transferred to other computers. This is not possible in a smaller installation. Third, it may be impractical for a banking unit in most communities to utilize a computer if the unit is required to bear the entire cost of a computer system. However, it will be practical to install a terminal in a branch bank connected to the central computer facility of the bank. To some extent the foregoing economies can be achieved by using a service bureau or time-sharing service; however, most banks will be reluctant to depend on computer equipment and software not under their direct control to perform critical accounting and control functions. Interviews with various bank data processing experts, Feb. 1974.

95. Some studies have shown average costs declining until banks reached $\$ 2$ million in assets and then remaining constant until $\$ 50$ million is reached. D. ALHADEFF, supra note 82 , at 83 . It may well be, however, that recent developments in computer technology have changed (and are changing) their calculations. See generally Schweiger \& McGee, Chicago Banking, 34 J. Bus. 203 (1961). 
drawals, for example, is greatly affected by the total number of accounts, since as they increase, fluctuation in total deposits decreases..$^{00}$

The above analysis suggests serious challenges to the proposals for regulatory reform. If, because of market characteristics, removal of market restraints will encourage the tendency to concentration, the resulting power of the dominant industry members could eliminate the advantages of competitive pricing. Not only may the goal of obtaining more home mortgage money not be achieved, but concentration could well lead to an increase in the cost of other loans without corresponding gains in deposit rates. ${ }^{97}$

Of course, this conclusion ignores the presence of compensating regulatory actions. As has already been mentioned, ${ }^{98}$ state banking laws can act to reduce as well as increase the factors of concentration in banking. On the whole, however, state regulation is too fragmented and unpredictable to serve as a fulcrum for a unified banking concentration policy. At the federal level, antitrust policy plays a substantial role, and indications are that Congress and the Justice Department are unwilling to accept lightly factors of additional concentration. ${ }^{90}$ And in the area of bank acquisition of other nonbanking businesses, the Bank Holding Company Act is designed to prevent concentration. ${ }^{100}$ But these regulatory schemes may be inadequate to deal with any tendency toward concentration resulting from proposals to allow

96. See P. SMIrH, supra note 82 , at $64-70$.

97. There is evidence to suggest that increase in the bank concentration ratio leads to increase in the interest rate on business loans. See Edwards, Concentration in Banking and Its Effects on Business Loan Rates, 46 REv. EcoN. STAT. 294-97 (1964); Edwards, The Banking Competition Controversy, 3 NaT'L BANKING Rev. 1 (1965). But see Flechig, The Effect of Concentration on Bank Loan Rates, 20 J. Fin. 298 (1965).

98. Sec pp. 1362-63 supra. One other area in which states may affect bank regulatory policy is the enactment of usury laws which may act independently to limit mortgage and other loan rates. Under the dual banking system there is little federal policy can do other than urge the removal of those ceilings if they conflict with interest rate ceilings or with the proposed removal of those ceilings. See Treasury Recommendations, supra note 3 , at 2 .

99. Under the Bank Merger Act of 1966, 12 U.S.C. $\$ 1828(c)$ (1970), a merger which would violate the antitrust laws (Clayton Act) can only be approved if its anticom. petitive effects are "clearly outweighed in the public interest by the probable effect of the transaction in meeting the convenience and needs of the community to be served." See id. \$ 1828(c)(5)(b); United States v. Phillipsburg Nat'l Bank, 390 U.S. 171 (1968); United States v. First Nat'l City Bank, 386 U.S. 361 (1967). See generally Lifland, The Supreme Court, Congress, and Bank Mergers, 32 Law \& Contemp. Prob. 15 (1967).

100. See Bank Holding Company Act Amendments of 1970, 12 U.S.C. $\$ \$ 1841-50$, 1971-78 (1970). The FRB administers the Act. For a critical evaluation of the FRB's performance, see STAFf RePORT, supra note 5, at 103-12. See also STAFF of House Comm. on Banking and Currency, 9lst Cong., Ist Sess., The Growth of Unregistered Bank Holding Companies-Problems and Prospects (Comm. Print 1969); Comment, Imple mentation of the Bank Holding Company Act Amendments of 1970: The Scope of Banking Activities, 71 Mich. L. REv. 1170 (1973). But see S. Talley, supra note 9I, at 22.23 (despite holding company acquisitions, nationwide banking concentration has declined by 2 percent from 1968 to 1973 ). 
banks and thrifts to compete freely. ${ }^{101}$ To some extent, antitrust policy in this field is limited by the countervailing tests of the Bank Merger Act of 1966 and the Bank Holding Company Act. ${ }^{102}$

Moreover, even if economies of scale do not dictate that bank failures will ultimately occur, the fear of increased competition may be enough to trigger a rash of bank mergers. The characteristic thrift institution reaction suggests that the threat of open competition may cause them to seek a merger partner rather than try to compete in an unregulated market. ${ }^{103}$ This could lead to a period of panic mergers which, if they are approved by the appropriate banking agencies, the Justice Department must review under the 30-day constraint of the Bank Merger Act. ${ }^{104}$ The increased Department workload might permit any number of bank mergers to be consummated without appropriate judicial scrutiny. ${ }^{105}$ It is possible, then, that the current proposals could result in the further concentration of an already highly concentrated banking industry, whether or not compelled by economic efficiencies.

101. Antitrust policy under the Bank Merger and Holding Company Acts has so far been thwarted by a judicial reluctance to apply the theory of potential competition, e.g., United States v. Falstaff Brewing Corp., 410 U.S. 526 (1973). See United States v. First Nat'l Bancorporation, Inc., 329 F. Supp. 1003 (D. Colo. 1971), aff'd by an equally divided Court, 410 U.S. 577 (1973). The Supreme Court currently has before it for decision two cases also rejecting the potential competition theory in banking. United States v. Connecticut Nat'l Bank, 362 F. Supp. 240 (D. Conn. 1973), prob. juris. noted, 94 S. Ct. 863 (1974): United States v. Marine Bancorporation, Inc., Trade Cas. I 94,496 (W.D. Wash. 1973), prob. juris. noted, 414 U.S. 907 (1974).

102. See note 99 supra. The Bank Holding Company Act contains the same test. 12 U.S.C. $\$ 1842(c)(2)(1970)$. Moreover, if economies of scale are shown to exist, the failing company defense may become relevant to antitrust enforcement. See Citizen Publishing Co. v. United States, 394 U.S. 131 (1969); Brown Shoe Co. v. United States, 370 U.S. 294 (1962). See generally Bok, Section 7 of the Clayton Act and the Merging of Law and Economics, 74 H.ARv. L. REv. 226 (1960).

103. Recently the New York Superintendent of Banks urged managements of thrift institutions not to "throw .. . in the towel" and merge because of the "expected onslaught" of statewide branching by outside banks which the new law may create in New York. See Albright Address, supra note 62 , at 15 ; note 91 supra.

The thrifts gave some indications of their fear of open competition when thcy successfully urged Congress to place interest ceilings on wildcard certificates of deposit. See Credit Crunch Hearings, supra note 8, at 57-60 (statement of Savings \& Loan League Chairman, Legis. Comm., Tom B. Scott, Jr.).

104. 12 U.S.C. $\$ 1828(c)(4)(1970)$.

105. Even without this additional enforcement burden there is evidence that the Department has been unable to restrain the tendency to bank concentration. In 1966, the 50 largest commercial banks held 44.4 percent of all commercial bank deposits; today they control about half. Since 1966, the Justice Department has labelled competitive effects of 106 proposed mergers "significantly adverse"; 76 of these mergers were approved by the various banking agencies over this objection and Justice challenged 49 of those approvals. The 106 challenges by Justice resulted from its review of 1,550 merger cases (a challenge rate of 6.8 percent). STAFF REport, supra note 5 , at 114. See note 99 supra. For an assessment of the lack of uniformity among the policies concerning merger approvals of the Justice Department, FDIC, and the Comptroller, see Eisenbeis. Difference in Federal Regulatory Agencies' Merger Policies, FDIC Working Paper No. 72-14 (1972). 
If, however, banking concentration is at least partially the result of economies of scale, there may be little reason to discourage realization of those economies. ${ }^{106}$ But traditionally this society has engaged in regulation of rates and entry, where the significant scale economies distort the competitive market, to ensure that the benefits of the economic efficiencies are passed on to the public. ${ }^{107}$ This is not, however, the focus of current regulation. The Administration and Patman proposals both seek to eliminate regulatory supervision over the marketplace without analyzing the need for economic regulation in the event that market concentration occurs. ${ }^{108}$ Since the empirical data on concentration building factors is not entirely clear, it may be that such concerns are ultimately misplaced. And indeed other federal and even state regulatory policies may be adequate to control any tendency to concentration that does occur. But if in fact banking competition is an idea worth exploring, and much evidence suggests that it is, then it must be encouraged on the one hand and observed carefully on the other. The role of the observer seems better suited to a regulatory agency with unified power and precise direction.

\section{The Separation of Commercial Bank Trust Departments}

Effective competition between thrift institutions and commercial banks must be predicated upon equality of opportunity in the marketplace. As has already been suggested, economies of scale may automatically place smaller institutions at a competitive disadvantage. While this may be an unavoidable condition, there is a more basic inequality in the present market structure that is not beyond regulatory adjustment. Large commercial banks have in recent years established trust departments which manage billions of dollars in pension, foundation, and trust assets. Most thrift institutions do not have the power to act as fiduciaries and the reform proposals have not recom-

106. See Wu \& Connell, supra note 83 , at 878-82.

107. See generally W. Jones, ReGULATED INDUSTRIEs (1967). See also Posner, Natural Monopoly and Its Regulation, 21 STAN. L. REv. 548-91 (1969) (queries the extent to which economic regulation is necessary to overcome the perceived market deficiencies of natural monopolies).

108. Of course the argument could be made that, if concentration results in excessive market power in the hands of large banks, direct economic regulation could be instituted at a later date. But failure to address the issue at this stage may effectively bury it forever. For example, since Congress has shown a reluctance to engage in economic regulation of oligopolies, the banking industry may stabilize below the monopoly level so as to avoid direct rate and entry regulation. See generally Goodwin, The American Condition, THE NEw Yorker, Feb. 4, 1974, at 48. 
mended granting them this power. Moreover, given the degree of concentration in trust department operations (which far exceeds that degree of concentration among commercial banks themselves), ${ }^{100}$ there would be little opportunity for emerging thrift trust departments to compete effectively in any event. This inequality suggests the more direct regulatory solution of separating large trust departments from their commercial bank parents.

\section{A. Definition and Scope of the Problem}

Sixty years ago Louis Brandeis wrote a series of articles, collectively entitled Other People's Money. ${ }^{110}$ The conclusions concerning the market power of the investment bankers which he drew there shocked many and led to some early reforms. ${ }^{111}$ But these reforms did not dissipate the "Money Trust" and Brandeis's conclusions are no less valid now. ${ }^{112}$

Today the market power of commercial banks like the First National City Bank and the Morgan Guaranty Trust Co. must be measured not only by their $\$ 27.7$ billion and $\$ 12.8$ billion in deposits but by the $\$ 17.1$ billion and $\$ 26.7$ billion investment portfolios managed by their trust departments. ${ }^{113}$ When aggregated this puts $\$ 40$ billion in assets under the control of one institution. And other large commer-

109. See notes 105 supra, 113 infra.

110. The articles appeared in Harper's Weekly during 1913 and 1914 and were later published in book form. See Hapgood, Foreword to L. BrandeIs, OTHER People's Money at xxviii (1933).

111. The Glass-Steagall Banking Act of 1933, 48 Stat. 162 (codified in various sections of 12 U.S.C.), was enacted to separate commercial banking from investment banking. But over the years the growth of pension funds (estimated to be $\$ 285$ billion by 1980 ) has led to a massive inflow of investable funds into bank trust departments. Since the Act does not apply to bank trust departments (which were then not the economic force they are today), it is an inadequate deterrent to market concentration and control in banking. See STAFF REPorT, supra note 5, at 97. But cf. Investment Company Institute v. Camp, 401 U.S. 617 (1971) (investment trust fund declared illegal under Glass-Steagall). And even in situations where the Glass-Steagall Act forced severance of banking and investment activities, connections may still be present. Thus it has been suggested that the Morgan Stanley investment banking house created as a result of the Act is still closely connected to its former parent, the Morgan Guaranty Bank, for whom the house performs underwriting and investment functions. See Tobias, The Establishment Bank Faces Life, N.Y. MAG., Oct. 29, 1973, at 40.

112. To some extent Brandeis's concentration data are outmoded. When he spoke of the "Money Trust" he referred principally to three New York banks; today those banks (J.P. Morgan \& Co., National City Bank, and First National Bank) are two. L. Brandeis, supra note 110 , at 19 (1933). Compare W. Douglas, Go East, Young MaN $292,440.47(1974)$.

113. See Am. Banker, Feb. 13, 1973, at 105; FRB, Trust Assets of Insured Comm. Banks-1972, at 70.

See also Senvite Comm. on Gov'r Operations, 93p Cong., Ist Sess., Disclosure of Corrorite OWNership Report 1 (Comm. Print 1973) [hercinafter cited as Senate CORP. OWNERSHIP RePORT]. The Report lists 28 institutional investors with assets over $\$ 5$ billion as of year end 1972. Of those 28, half are commercial bank trust departments. 
cial banks are of comparable size. ${ }^{114}$ At the end of 1971, commercial bank financial assets and trust department assets accounted for almost 60 percent of the total assets of all institutional investors. ${ }^{115}$ Because of director interlocks (especially with life insurance companies) these banks also control indirectly even larger portfolios. ${ }^{110}$

The asset power of the commercial banks has a profound impact upon the economy. One consequence is the creation of a two-tier market in which stocks of larger companies trade at higher multiples of earnings than do stocks of smaller companies. ${ }^{117}$ Since large trust departments invest heavily in large companies, ${ }^{118}$ the commercial side has tended to complement those investments with loan policies that necessarily restrict the availability of loans to smaller companies.110 This drives down the earnings multiples of those companies and seriously impinges upon the ability of new companies to enter the market, thereby ultimately having an impact upon the entire economy.

Moreover, this kind of investment concentration in larger companies may lead to investment decisions and loan policies, with respect to those companies, that are tainted by conflicts of interest. ${ }^{120}$ For example, 22 percent of the Penn Central Company's common stock was held by bank trust departments; and these same banks through director interlocks controlled much of the company's decisionmak-

114. Also in the $\$ 30$ billion category are the following banks (trust assets in billions listed first; deposits sccond): Bank of America (\$6.5; \$35.4); Chase Manhattan Bank (\$16.2; \$25.0); Bankers Trust Co. (\$19.9; \$10.6); American Banker, supra note 113; FRB, supra note 113 , at 70 .

115. STAFF REPORT, supra note 5, at 93. This total was divided between commercial banks' financial assets ( 37.4 percent) and trust assets (21.8 percent). The other large institutional investors were life insurance companies (14.4 percent), savings and loans banks (13.3 percent), and mutual savings banks ( 5.8 percent).

116. See p. 1369 infra.

117. See Credit Crunch Hearings, supra note 8, at 886-87 (statement of James Necdham, Chairman of N.Y. Stock Exchange); SENATE CORP. OWNERSHIP REPORT, supra note 113, at 12.

118. The Morgan Guaranty Trust Company is said to have held, as of 1967, the following percentages of the total outstanding common stock (most of it with voting rights) of the following major companies: Xerox (9.7 percent), Polaroid (5.5 percent), Burlington Industries (14.5 percent). Other large bank trust departments showed similar degrees of control. STAFF REPORT, supra note 5, at 95. As of 1972, Miorgan's Xerox holdings were said to be down (to 5.0 percent), but its Polaroid holdings were up (to 10.2 percent) and it held 4.5 percent of IBM common stock. Tobias, supra note 111 , at 41 .

119. See Senate Corp. Ownership Report, supra note 113, at 1-2. The Committee on Publicly Held Companies (a group of 562 smaller corporations) has complained that its members are frequently closed out of the credit market because of bank trust department concentration "on a few religion stocks." Credit Crunch Hearings, supra note 8, at 985, 986. But see U.S. Treas. Dep't, Public Policy for American Capital Markets, reprinted in BNA 1974 SEC. REG. L. REP. No. 239, at D-1 (Feb. 13, 1974).

120. Conflicts of interest have also been shown to exist in the savings and loan industry where close relationships with real estate, insurance and construction activities (often through director interlocks) lead to loan policies that restrict competition. See Herman, Conflict of Interest in the Savings and Loan Industry, STUDY OF THE SAvingS AND LOAN INDUSTRY 44, 763-69 (I. Friend ed. 1969). 
ing. ${ }^{121}$ When the company's bankruptcy was in the offing, directors of the Penn Central who were also directors of banks had to decide whether to make further loans or stock purchases, or conversely to sell out the trust department's investment prior to public disclosure. ${ }^{122}$ In both situations the potential for conflicts of interest was plain. ${ }^{123}$

It is also undoubtedly true that the voting power of bank trust departments has a major impact on corporate policy; but so far that impact has not been measured accurately. Bank trust departments maintain significant holdings in nominee accounts, ${ }^{124}$ a practice which effectively disguises their true voting power. ${ }^{125}$ Nevertheless, the known voting rights of some bank trust departments are substantial enough to provide effective control over many major corporations. ${ }^{126}$ There is also evidence to suggest that major commercial banks are, through trust departments, heavy investors in each other. ${ }^{127}$

Large bank trust departments pose serious challenges to the effective regulation of the banking industry under current law. If de-regulation becomes a desired goal, the bank trust department problem becomes much more pronounced, especially for its influence upon the ability of thrifts to compete. But the Administration's legislative proposals have not confronted this necessary connection between industry deregulation and bank trust department separation.

121. Of the Penn Central's 23 directors, 16 were directors of 19 banking institutions. STAFF REPORT, supra note 5 , at 95.

122. Id.

123. A recent congressional study of 49 banks in 10 major cities revealed some 8,000 interlocking directors associated with more than 6,500 companies. More than 750 of the interlocks were with companies in the top 500 industrial companies. Id. at 97.

124. A nominee is "a person (or persons) designated to represent or take the place in name only of another person, bank, company, or corporation." G. FISCHER, AMERICAN Banking Structure 88 (1968).

125. A recent congressional study under the direction of Senator Lee Metcalfe revealed that bank trust departments utilize nominees more than any other institutional investor. The use of nominees is especially prevalent in public utility reports. For example, the Long Island Lighting Company listed in a report to the Federal Power Commission its ten top shareholders, five of which were nominees with the same New York City Post Office address at Church Street Station. Two of those nominees turned out to be Chase Manhattan and three Morgan Guaranty. See SEnAtE Corp. OWNERSHIP REPORT, supra note 113, at 9-10.

126. If 10 percent is taken as the benchmark of control, available data show several banks with control of major corporations. For example, FCC data show Chase Manhattan Bank to hold voting rights to 14 percent of CBS and Bankers Trust to have voting rights to more than 10 percent of ABC. Id. at 8 . See note 118 supra. See also Securities Exchange Act of $1934 \$ \S 13(\mathrm{~d}), 14(\mathrm{~d}), 15$ U.S.C. $\$ \S 78 \mathrm{~m}$ (d), 78n(d) (1970) (reducing control for ownership reporting purposes from 10 percent to 5 percent).

127. The data are difficult to obtain. There is no mandatory reporting requirement under federal banking law, and Senator Metcalfe's request for top stockholders of large commercial banks met with limited responses (24 of the 50 largest banks refused to provide any information). Some did reply in at least limited fashion. The Chase Manhattan and Morgan Guaranty banks, for example, revealed that nominees held much of their stock, and Morgan acknowledged that among its 30 largest stockholders were 17 nominees of 10 commercial banks. See SENATE CORP. OWNership RePort, supra note 113 , at $9-10$. 


\section{B. Critique of Proposals for Bank Trust Department Reform}

There is no shortage of proposals for bank trust department reform. Most, however, propose solutions short of absolute separation from commercial banks. The most popular solution, described by a metaphor, is building a "wall" between the two banking functions within the commercial bank. ${ }^{128}$ To construct this wall so as to avoid the potential for conflicts of interest and self-dealing, recommendations have been made for improving the bank examination process and the collection of data about bank securities and portfolio management policies. ${ }^{129}$ The Hunt Commission Report echoes this theme by recommending that bank examining agencies investigate and monitor the performance of bank trust departments. ${ }^{130}$ Although the Administration's reform proposals largely rely upon the Hunt Commission for inspiration, they are silent on the question of bank trust department regulation.

The Patman proposals, on the other hand, directly attack the bank trust department problem by requiring the complete separation from commercial banks of all trust departments with trust assets in excess of $\$ 200$ million. ${ }^{131}$ The effect of this proposal, if implemented, would be to divest from their commercial bank parents some 250 trust departments (which control 89 percent of all trust assets) and leave intact the remaining 3,374 bank trust departments. ${ }^{132}$ This solution, labeled radical by American Bankers Association spokesmen, ${ }^{133}$ has

128. See Herman \& Safanda, Commercial Bank Trust Departments and the "Wall," 14 B.C. IND. \& CoM. L. REv. 21 (1972).

129. See Lybecker, Regulation of Bank Trust Department Investment Activities, 82 YALE L.J. 977 (1973) [hereinafter cited as Lybecker, Regulation]; Lybecker, Regulation of Bank Trust Department Investment Activities: Seven Gaps, Eight Remedies (Part II), 91 BANKing L.J. 6 (1974). Lybecker has worked out in great detail proposals for improved policing of trust department performance.

130. HUNT Comm'N REPORT, supra note 4, at 101-06. For example, the Commission recommended that bank trust officers be subject to a "prudent man rule" for investments in pension funds, as they now are for personal trust funds, and that they be prohibited from using inside information received from the commercial side. The Commission opposed the absolute separation of trust departments for fear that it would result in a loss of trust services in many smaller areas due to inherent economies of scale in the investment of funds. $I d$. at 104. To implement its proposals, the Commission recommended that thrift institutions be given the additional power to operate trust departments. The Financial Institutions Act, however, has not incorporated this additional power in its reform proposals.

131. See STAFF REPORT, supra note 5, at 98-101. This $\$ 200$ million limit parallels the Hunt Commission's limit for the point at which trust departments should be denied access to commercial banking department credit information. HuNr Comm' $N$ REPORT, supra note 4, at 101 . The Patman proposals prohibit use of commercial bank information by the smaller trust departments as well. STAFF REPORT, supra note 5, at 100 .

132. STAFF REPORT 100. The proposals also outline the rudiments of a new regulatory body, the Federal Trust Management Commission, whose function it would be to supervise the management of all trust, pension, and foundation funds. See id. at 102.

133. See Am. Bankers Ass'n, supra note 54, at 25-27. 
triggered widespread industry concern..$^{13 \pm}$ While it is a bolder proposal than others, ${ }^{135}$ it is the only reform measure that relates directly to the other proposals for de-regulation.

The industry's ostensible objection to separation as a reform measure is that trust departments cannot exist on their own. ${ }^{136}$ But reliable data seem to demonstrate that the unprofitability argument is based on incomplete bookkeeping that fails to allocate to the trust department large amounts of noninterest bearing demand deposits on the commercial side. ${ }^{137}$ If that allocation is made, there is evidence that the overall venture is profitable for banks. It has been estimated, for example, that the value of those deposits to the bank adds (indirectly) 30 percent to bank trust department compensation. ${ }^{138}$

If trust departments truly are unprofitable, it is difficult to understand why banks fight to retain them. Since the present fee structure plus indirect demand deposit income are unable to support the operations of trust departments (especially small ones), ${ }^{139}$ one might doubt whether commercial bank customers should be subsidizing trust account customers. This kind of internal subsidization favors a class of beneficiaries not generally deemed in need of protection. Certainly the argument against separation is not strengthened by such considerations. Once trust departments are made independent they can seek upward revision in fee structure from the appropriate regu-

134. One recent response, from the American Bankers Association's Trust Division, sought to rebut some of the charges against large trust departments by collecting data on size of accounts, concentration, and diversification in bank trust departments. See Am. Bankers Ass'n, Survey Report: Equity Trading and Investment by Trust Departments, 1974. It is difficult to understand why the kind of data this industry survey seeks to provide were not available to regulators as a matter of course on a more reliable basis; the survey was anonymous, unsworn, and incomplete (only 20.7 percent responded).

135. Ralph Nader, for one, has testified that a complete separation of trust departments may not be necessary if trust department securities holdings are disclosed and the bank is forbidden to have commercial banking relations with corporations whose equity securities it holds. See Credit Crunch Hearings, supra note 8, at 472. This solution, while formally eschewing separation, seems ultimately to create more regulatory problems than it solves.

136. See StafF ReporT, supra note 5, at 100. See generally C. Golembe, The Economic Power of Commercial Banks, 1970 (Am. Bankers Ass'n publication).

137. The SEC Institutional Investor Study showed that these demand deposit balances in the 50 largest trust departments amounted to $\$ 1.5$ billion at the end of 1969 . STAFF REPORT, supra note 5, at 100 . Trust departments generate these deposits during the period between purchase of securities and payment for them, between the sale of securities and reinvestment, and between the receipt of dividends and investment income and their disbursement. See HuNT COMM'N REPORT, supra note 4, at 105. This activity may generate conflicts of interest when the bank is losing demand deposit income to investments in short-term commercial paper and Treasury Bills. One way to reduce the impact of this problem, by paying interest on demand deposits, has not been adopted in the Administration's legislative proposals. See note 39 supra. 138. SEC, Institutional Investor StUdy REPORT, H.R. Doc. No. 92-64, 92d Cong., 1st Sess. (1971).

139. See note 147 infra on brokerage fees and investment advisor information. 
latory agencies. ${ }^{140}$ It may be that economies of scale will dictate a concentration of these independent trust departments with other investment advisers, but in that event the resulting entity will not contribute to concentration in the commercial banking industry. ${ }^{141}$

The separation solution assumes that building a "wall" of silence and nondisclosure between the trust and commercial banking departments is an inadequate alternative. There are serious reasons to doubt that the wall will be high enough to sever interchange between one side of the bank and the other. A bank's directors by definition sit astride this wall and invariably learn what both departments are doing. ${ }^{142}$ Moreover, trust department disclosure requirements frequently compel public disclosure of the largest blocks of voting stock. ${ }^{143}$ Given these limitations, attempts to build effective internal walls are unlikely to succeed. In addition, no matter how impregnable the wall may appear to be, leaks will inevitably occur. ${ }^{144}$ For example, the exchange of inside information can occur even though the wall itself is intact, because of the bank's multiple relationships. Where the bank is both a major shareholder and a major creditor of a listed company, information may flow directly to the trust department from company management, who are concerned about protecting good relations with all departments of the bank. ${ }^{14 \bar{s}}$

It is unrealistic to think that all of these practices will be overcome merely by separating bank trust departments as the Patman proposals recommend. Certainly, in the short run at least, many of the new entities, after separation from the parent body, will retain essentially the same stockholders, which may themselves be major commercial banks. ${ }^{146}$ But most of the major problems of bank trust department behavior stem from affiliation with a commercial bank. ${ }^{147}$ The market

140. The fee structure is often set by state laws. See Lybecker, Regulation, supra note 129 , at $1001-02$.

141. See p. 1367 supra.

142. See Credit Crunch Hearings, supra note 8, at $472-73$ (statement of Ralph Nader).

143. See StAFF REPORT, supra note 5, at 99-100. The existing disclosure requirements will be greatly augmented if some recently proposed regulations of the Comptroller of the Currency are adopted. See N.Y. Times, Apr. 20, 1974, at 39, col. 7.

144. An often cited example of this problem is the Penn Central failure, where some trust departments allegedly had advance word from bank loan officers on when to sell out. See pp. 1368-69 supra. See also Schotland, Conflicts of Interest and Bank Trust Departments-A Provocateur's Perspectives, Oct. 1973, at 10.

145. On this and other matters discussed in this section, the author benefited from discussions with Professor Roy Schotland of the Georgetown University Law Center and from Schotland, supra note 144.

146. One of the difficulties in measuring the potential impact of continued commercial bank representation on the diverted entity is the difficulty in obtaining knowledge about commercial bank shareholders. See note 127 supra.

147. Bank trust department operations also threaten competition in the provision of investment services. The market for investment advisory services is dominated by 
power of the resulting combination is so great and the conflicts of interest so endemic that building an effective wall is virtually impossible. And the irony is that if a true wall is achieved, the result would in practical effect eliminate the distinction between the separated and unseparated (but walled) entities. Ultimately, therefore, the arguments in favor of a true wall blend into those for separation. ${ }^{148}$

Since there is little evidence that bank affiliation by itself produces superior trust department performance, ${ }^{149}$ and since separation will obviate the need for close regulatory supervision implicit in the wall concept, there seems little reason to resist separation. Moreover, the kind of regulatory intervention necessary to ensure the maintenance of a true wall is inconsistent with the free market philosophy of the Administration's proposals. The only defense of the present structure is that offered by the Hunt Commission, which concluded that if separation occurred, economies of scale would deprive smaller communities of needed trust services. ${ }^{150}$ It would seem that the $\$ 200$ million asset limitation on separation contained in the Patman proposals would protect against that possibility and allow smaller communities to retain trust department services within their local banks. ${ }^{151}$

In balance then the creation of separate trust departments should be a welcome addition to the Administration's proposals for returning competition to the banking field. Certainly the ability of thrift institutions to compete in this reordered market would be enhanced if they had to face commercial banks alone and not commercial banks buttressed by the market power of trust departments.

bank trust departments, which are larger than all other institutional investors combined. See Lybecker, Regulation, supra note 129, at 977. Large trust departments are able to negotiate lower commissions with brokerage houses on block purchases and sales and obtain extensive investment information services. See Credit Crunch Hearings, supra note 8, at 887 (statement of N.Y. Stock Exchange President James Needham). There is also some reason to believe that these large trust departments are able to encourage reciprocal deposits from brokerage houses as a condition to execution of trust account orders. See HUNT CoMm'N REPORT, supra note 4, at 104; STAFF REPORT, supra note 5 , at 99 .

148. Governor Jeffrey M. Bucher of the FRB has recently recommended that bank trust departments affiliated with commercial banks belonging to the same holding company be consolidated into a separate subsidiary corporation within the holding company. Governor Bucher believes that this kind of separation is essential because, "as a matter of public perception, regardless of what is believed by trust men, the Chinese Wall lacks sufficient strength to resist the abuses of economic power and conflict of interest." Address by J. Bucher, Conference of Western Section of ABA Trust Div., Sept. 21, 1973, at 15-17. While holding company separation is a middle ground between wall building and complete spin-off, it would seem to achieve the same goals as spin-off, at least until the market changes the stockholders.

149. Bank trust departments are not free of charges of trust mismanagement. See STAFF REPORT, supra note 5, at 101-02.

150. HUNT COMM'N REPORT, supra note 4, at 104-05.

151. See p. 1370 supra. 


\section{Reform of the Institutions of Reform}

Banking law reform may be seen as both private and public, and realignment of the members of the industry is in some respects no more important than reorganization of the relevant regulatory agencies. If, as frequently claimed, the industry's performance is restrained by a residue of laws emanating from the Depression psychosis, ${ }^{162}$ so too is effective regulation hindered by agencies with overlapping jurisdictions. While banking laws were passed in periods of national financial crisis without any well-conceived master plan, the current proposals for private industry reform are offered as studied, noncrisis alternatives to existing regulation. ${ }^{153} \mathrm{~A}$ reevaluation of proposals for public agency reform in order to produce a unified institutional approach to implement the goals of reform is thus timely as well.

\section{A. The Present Regulatory Structure}

Regulation of banking is a subject as old as the republic itself. ${ }^{154}$ Initially, the issue of regulation was entangled in disputes over federal and state power, and the early Congress was reluctant to charter banks without state approval. ${ }^{165}$ The result was that by and large the banking field was left to regulation by the states. ${ }^{156}$ It was not until the Civil War that federal regulation asserted itself and created what came to be known as the "dual banking system."157

152. See Credit Crunch Hearings, supra note 8 , at 473 (statement of Ralph Nader).

153. This is a conclusion that can be drawn both from the President's Message to Congress of August 2, 1973, proposing the reforms, and the Hunt Commission Report which suggested them. See HuNr Comm'N REPORT, supra note 4, at 7-9; Treasury Recommendations, supra note 3, at 1-3. Other countries have experienced similar crisis pressures on banking regulation that have in some cases led to highly concentrated markets. See generally D. AlmadefF, CoMpetition and Controls in Banking (1968) (England, France and Italy).

154. In fact what is said to be the first genuine bank in the colonies predated the formation of the Republic. Called the Bank of North America, it was formed in 1781 under a resolution by the Continental Congress. The First and Second Banks of the United States were set up by congressional enactments in 1791 and 1816. Act of Feb. 25, 1791, ch. 10, $\S 7(X V), 1$ Stat. 191; Act of Apr. 10, 1816, ch. 44, $\$ 11(X I V)$, 3 Stat. 266. See W. Hurst, A Legal History of Money in the United States, 17741970 , at $134-51(1973)$.

155. The Bank of North America had apparently been chartered originally by the Continental Congress but, because of doubt as to that body's power to act, the Bank also obtained a charter from the Pennsylvania legislature. In 1784, the Bank of Massachusetts and the Bank of New York followed the same procedure. G. Fisciier, supra note 124 , at 9 .

156. With the exception of the Bank of North America and the First and Second Banks of the United States, all banks prior to 1863 were state chartered. G. FISCHER, supra note 124, at 15 . By 1863 , there were 1,466 state banks. See BOARD of Governors of the Federal Reserve System, Banking Studies 418 (1941).

157. The discussion of regulatory reform will be limited herein to reform at the federal level since that is the context of the current reform proposals. This does not mean, however, that the issues raised by the dual banking system are also not 
The federal government enacted the first significant bank regulation in 1863, when the National Bank Act was passed in order to create a new currency to finance the war effort. ${ }^{158}$ The National Bank Act established in the office of the Comptroller of the Currency the first of the federal regulatory bodies that presently assert control over banking. The Comptroller was authorized to regulate the national currency and to approve the establishment of national banks. ${ }^{159}$

The Federal Reserve Act of $1913^{180}$ created the next significant regulatory agency, the FRB. To overcome concern about rapid expansion of credit, the Act required national banks to become members of the Federal Reserve System and directed the Board to establish more effective supervision of banking. ${ }^{161}$ The Act also extended for the first time federal supervision to state banks which, on a voluntary basis, were allowed to become members of the system. ${ }^{102}$ The Comptroller of the Currency, while still considered to be in charge of the national banking system, was made an ex officio member of the FRB. ${ }^{163}$

A third regulatory body, the FDIC, was established by the Banking Act of 1933. ${ }^{164}$ This Act required the federal government to insure deposits in all national banks and state banks which had become members of the Federal Reserve System: it also permitted state banks which were not members of the system to obtain insurance. ${ }^{165}$ Today all but a few of the 14,000 commercial banks in the United States are insured by the FDIC. ${ }^{168}$ Over the years, the FDIC acquired ex-

important. Certainly, branch banking regulation and usury laws reveal that there are significant regulatory problems posed by the dual sovereignty concept.

While this dual system still exists today, many feel that state authority could be effectively overridden if the Congress ever decided to impose mandatory reserve requirements on state banks. See Credit Crunch Hearings, supra note 8, at 424 (remarks of Rep. Stephens). And recently the FRB has submitted to Congress proposed legislation extending reserve requirements to nonmember institutions (commercial banks, mutual savings banks and S\&Ls) that issue demand or other types of deposits and perform a checking account function. See Letter with enclosures from Arthur S. Burns to Wright Patman, Jan. 25, 1974.

158. See G. Fischer, supra note 124, at 18-19. See also B. Hammond, Banks and Politics in AMERICA, From the ReVolution to THE CiviL WAR (1957); Hackley, Our Baffling Banking System, 52 VA. L. REv. 565, $570-73$ (1966).

159. Act of Feb. 25, 1863, ch. 58, \$1, 12 Stat. 665.

160. Act of Dec. 23, 1913, ch. 6, $\$ 2,38$ Stat. 251.

161. See Hackley, supra note 158 , at 574-75.

162. Act of Dec. 23, 1913, ch. 6, § 9, 38 Stat. 259.

163. The FRB was empowered "to instruct the comptroller upon all necessary matters ...." H.R. Rep. No. 69, 63d Cong., 1st Sess. 43-44 (1913). See Hackley, supra note 158 , at 575 . The Comptroller no longer sits as a member of the FRB.

164. Act of June 16, 1933, ch. 89, 48 Stat. 162. See Act of Sept. 21, 1950, ch. 967, 64 Stat. 873, as amended, 12 U.S.C. $\$ \$ 1811-31$ (1970).

165. Nonmember state banks were actually extended insurance privileges in a series of subsequent amendments. See Hackley, supra note 158, at 577-78.

166. See StAFF REPORT, supra note 5, at 55. 
panded powers over nonmember state banks, including control over the payment of interest on deposits, the establishment of branches, and bank mergers. ${ }^{167}$

These three agencies are the ones principally concerned with the regulation of banks. ${ }^{168}$ Their jurisdictions have understandably become thoroughly entangled. The Comptroller, the FRB, and the FDIC share jurisdiction over national banks; the FRB and the FDIC share jurisdiction over state banks that are members of the Federal Reserve System; and the FDIC regulates insured nonmember banks. In addition, the FRB regulates bank holding companies for all types of banks, even the small residual category of state, nonmember, noninsured banks. ${ }^{169}$ Congress has done little to reconcile these jurisdictions; ${ }^{170}$ instead it has left intact what has been described as a confusing, inefficient, and inequitable pattern of regulation. ${ }^{171}$

A good example of this current pattern is the regulatory scheme established by the Bank Merger Act. ${ }^{172}$ Under this Act, initial jurisdiction over mergers is divided among the three banking agencies according to the nature of the resulting merged bank. ${ }^{173}$ In addition, each banking agency, as well as the Department of Justice, is required to prepare advisory opinions on each proposed merger for submission to the agency with primary responsibility. ${ }^{174}$ Aside from the seeming

167. See 12 U.S.C. $\$ \S 1828$ (c), (d), (g) (1970).

168. The activities of two other federal agencies, the Department of Justice and the SEC, also have an impact upon banking. Justice applies the antitrust laws to bank holding company acquisitions and bank mergers under the Holding Company Act and the Bank Merger Act. See 12 U.S.C. $\$ \$ 1841-50,1971-78$ (1970); id. $\$ 1828$ (1970). The disclosure requirements of the Securities Exchange Act of 1934 are applied to banks with widely held stock and trust investment accounts. See 15 U.S.C. $\$ 781$ (1970); Hackley, supra note 158 , at 579-80, 786-92.

169. See 12 U.S.C. $\$ \$ 1841-50,1971-78$ (1970). See generally Comment, supra note 100.

170. One exception to congressional diffusion of regulatory authority has been the granting of exclusive jurisdiction over regulated bank holding companies to the FRB in 1956. Bank Holding Company Act of 1956, ch. 240, 70 Stat. 133, as amended, Act of July 1, 1966, Pub. L. No. 89-485, 80 Stat. 236, as amended, Bank Holding Company Act Amendments of 1970, Pub. L. No. 91-607, 84 Stat. 1760. But even here there have been unsuccessful legislative attempts to divide jurisdiction among the three banking agencies. See STAFF REPORT, supra note 5, at 56.

171. See Hackley, supra note 158, at 799-814 (the author is General Counsel of the FRB); Address by Governor J.L. Robertson of the Federal Reserve Board, BANkING, June 1962, at 41 .

172. Act of May 13, 1960, Pub. L. No. 86-463, 74 Stat. 129, as amended, 12 U.S.C. $\S 1828$ (1970). See United States v. Philadelphia Nat'l Bank, 374 U.S. 321 (1963); G. FisCHER, supra note 124, at 122-74, 276-310.

173. The appropriate agencies are the Comptroller of the Currency if the surviving bank is a national bank, the FRB if the survivor is a state-chartered, member bank, and the FDIC if the survivor is a state-chartered, nonmember bank. 12 U.S.C. $\$ 1828(c)(2)$ (1970).

174. The Bank Merger Act of 1966 provides that mergers which would otherwise violate the antitrust laws are legal if their anticompetitive effects are "clearly outweighed" by the probable effect of the merger in meeting the "convenience and needs of the community." Id. $\S 1828(\mathrm{c})(5)(\mathrm{B})(1970)$. See generally Lifland, The Supreme Court, Congress, and Bank Mergers, 32 LAw \& ConteMp. ProB. 15, 28.32 (1967).

\section{6}


inefficiency of four agencies commenting upon the same transaction, the disparate views of these agencies in interpreting the same legislation has led to confusion and forum shopping. A comparison of advisory opinions shows, for example, that the Comptroller of the Currency more often favors mergers than do the other three agencies. ${ }^{175}$ As a result, merger partners seek to place themselves in a position to be reviewed by the Comptroller, and the Justice Department becomes a watchdog "fourth banking agency" forced to attack these approved mergers, and fight the other agencies, in court. ${ }^{176}$ This difference in views among the banking agencies necessarily has the effect of frustrating basic policy objectives. And the regulating that occurs is characterized more by jurisdictional jealousies than by informed decisionmaking. ${ }^{177}$

\section{B. Critique of Proposals for Institutional Reform}

Given these institutional squabbles, ${ }^{178}$ it is not surprising that both industry and regulators have favored institutional reform for many years. ${ }^{170}$ What is surprising is the inattention which institutional re-

175. A study of bank merger advisory opinions from 1960 to 1969 revealed the following approval rates (based upon dollar value of the merger assets): The FRB found adverse competitive effects in 67 percent of the cases under its jurisdiction, while the figure for the Justice Department was 59 percent. The FDIC, however, disapproving 53 percent of its cases, was more lenient than Justice, which disapproved 67 percent of the same cases. The Office of the Comptroller was even more lenient; it disapproved only 35 percent of its cases, whereas Justice disapproved 75 percent. STAFF REPORT, supra note 5 , at 59 .

176. For a defense of the Comptroller's decisions on economic grounds and an attack on the Justice Department's interference with the banking agencies, see Wu \& Connell, supra note 83 , at $870-82$.

177. As Governor J.L. Robertson of the FRB observed about the entire regulatory system:

I am convinced that the people of this country will not-and should not-be satis-

fied with a system that by its very structure almost invites pettiness and bickering,

in which one group of banks can be played against the other, and where, in the

name of equity and fairness, bank supervisory standards are increasingly reduced

to the level of the lowest or nost lenient.

BANKING, June 1962, at 41 .

178. Id. See STAFF RePort, supra note 5, at 58.

179. Shortly after Congress established the FDIC, a Brookings Institution study of government financial agencies proposed institutional reforms. See S. REP. No. 1275, 75th Cong., lst Sess. 222-23 (1937). For a detailed discussion of this and other reform proposals, see Hackley, supra note 158 , at $799-808$.

An Advisory Committee on Banking, which contained several prominent bankers, recommended in 1962 that the supervisory functions of the federal agencies be divided among the FDIC and the Comptroller, eliminating the FRB's role in this area. See Advisory Comar. on Banking to the CoMptroller of the Currency, National BANKS AND THE Future (1962). A more dramatic proposal was that of Governor Robertson of the FRB; he proposed the abolition of the FDIC and the Comptroller and would place the FRB's supervisory functions in the hands of a single Federal Banking Commission. See Hackley, supra note 158, at 805-08. That proposal appears to form the underpinning for the current Patman proposals. 
form has received in the Administration's legislative proposals. ${ }^{180}$ The Financial Institutions Act is silent on the subject, and the Hunt Commission offered little in the way of basic changes. ${ }^{181}$

The Patman proposals, on the other hand, are quite specific in describing recommended reforms. They recommend establishment of a single regulator, the Federal Banking Commission. ${ }^{182}$ The agency is to inherit all of the supervisory and examining functions of the three federal agencies. The Comptroller of the Currency would cease to exist and the FDIC would still receive and collect deposit insurance but would be under the control of the new Commission. ${ }^{183}$

The Holding Company Act and Truth in Lending Act responsibilities of the FRB would be transferred to the new Commission but the FRB's monetary policy functions would in no way be affected.184 The proposals also recommend the establishment of an Office of Public Counsel to advocate public interest issues before the Commission in proceedings over the approval of bank holding company acquisitions and bank mergers. The Public Counsel would also have responsibility for administration of the Truth in Lending Act, currently in the hands of the FRB. ${ }^{185}$

The idea of a single agency has strong opponents. Understandably, the agencies themselves have an interest in their own existence, but perhaps the most curious opposition comes from the Department of Justice, which takes the position that jurisdictional competition among agencies is an assurance of effective regulation. A spokesman stated that "a single agency with responsibility for everything . . . will frequently become highly protective of the firms that it is responsible

180. Consider, for instance, the Administration's tendency to recommend reorganization elsewhere. See U.S. President's Advisory Council on Executive Organization, A New Regulatory Framework (1971); Federal Energy Regulation Study Team, Federal EnERgy: An Organizational Study (1974).

181. The Hunt Commission recommended agency name changes and some limited changes in functions (the FRB's regulatory functions, minus Holding Company Act responsibilities, were to be transferred to an Administrator of State Banks), but recommended little to consolidate agency decisionmaking. See HUNT CoMM'N REPORT, supra note 4, at 87-95, 119-20; cf. Senate Hearings, supra note 7, at 6 (statement of Recd Hunt). Its recommendations have been criticized as perpetuating "the confusion and conflict in federal bank regulations in a slightly different form." STAFF REPORT, supra note 5, at 62. The Treasury Recommendations, supra note 3 , and the Financial Institutions Act, supra note 6 , make no reference to those proposals.

182. See STAFF Report, supra note 5, at 62-65.

183. It should be noted that Chairman Patman earlier supported a reform pro. posal that would have consolidated all federal bank regulation in the Treasury Department. See H.R. 6885, 89th Cong., 1st Sess. (1965).

184. See STAFF REPORT 62-65.

185. Id. at 62. The Commission would consist of five members appointed by the President for five-year terms; one member must have had experience in state banking supervision and another must have been a Governor of the FRB. Id. at 63 . 
for and will tend to prevent any one of them from taking advantage of its various efficiencies." 186

This faith in agency competition seems misplaced given the current squabbles in these agencies over appropriate regulatory standards, especially with respect to bank mergers. ${ }^{187}$ And while it is a cliche of our time that a single agency can be coopted by those it regulates, ${ }^{188}$ there is no reason to believe that the present multiagency arrangement is free from such pressures. Indeed, it is the opportunity for forum shopping in the present structure that has led to the current trend toward the least abrasive regulation. ${ }^{180}$ The present multiagency concept, therefore, may offer not vigorous agency competition, as the Department of Justice contends, but rather an opportunity for those regulated to divide and conquer. A single agency is of course not free from comparable pressures, but it would be more visible and therefore subject to closer political and judicial supervision. There is no reason automatically to accept the cynical conclusion that there is an absolute correlation between the locus of government power and the degree of cooptation by private interests. Moreover, the single agency concept offers opportunities for achieving administrative efficiencies not currently available. Few doubt that a single agency will achieve significant economies in reducing the present agency structures by two. ${ }^{190}$

The single agency concept is vitally important to the proposals for banking competition. One of the fears in connection with this new competition is that thrift institutions and smaller banks will perceive themselves to be at a competitive disadvantage with the large commercial banks and rush into bank mergers or holding company affiliations. In the present structure, these mergers may be achieved in many cases by shopping for jurisdiction within one of the more permissive agencies such as the Comptroller of the Currency. ${ }^{101} \mathrm{~A}$ single agency

186. Credit Crunch Hearings, supra note 8, at 528 (statement of Donald Baker, Director of Policy Planning, Antitrust Div., Dep't of Justice). Accord, HuNT Comm'N REPORT, at 60. See also Senate Hearings, supra note 7, at 24 (statement of William E. Simon).

187. Even Justice balks at the presently divided agency responsibility over bank mergers. Calling the system "perverse," it recommended consideration of a centralized merger agency. Id. at 534 .

188. The Justice Department cites as evidence of this possibility regulation of transportation by the Interstate Commerce Commission. Credit Crunch Hearings, supra note 8, at 528. See Stigler, Theory of Regulation, 2 Bell J. Econ. MGr. Scr. 3 (1971).

189. See note 177 supra.

190. Eliminating duplicative agency staff functions (e.g., three examining staffs) should provide regulatory cost reductions. See STAFF REPORT, supra note 5, at 64-65.

191. The Justice Department may second-guess other agency decisions, but its supervision is limited and somewhat haphazard. In the period 1960 to 1970 , the Justice Department brought only 70 cases. Credit Crunch Hearings, supra note 8, at 526-27. See also notes $105 \& 175$ supra. 
with a clear understanding of its role would be able to supervise mergers and affiliations and to implement regulatory policy in a fashion beyond the capabilities of the truncated multiagency concept. Furthermore, if the presence of significant economies of scale in banking is confirmed, a single agency will be needed to measure the need for industry consolidation and to monitor the industry to determine if rate and entry restrictions are or should be appropriate.

\section{Conclusion}

A series of recent proposals for reform of financial institutions, and the prospect that the next Congress will carefully address these proposals, indicates that this is an opportune time to consider fully all aspects of reform. The Administration has already submitted a legislative proposal, the Financial Institutions Act of 1973, which it bills as a total package of reforms. In reality, however, it takes a rather narrow approach to reform, in that it focuses principally upon one solution-de-regulation of the marketplace-to meet several professed social goals.

Certainly there is reason to believe that interest rate ceilings and other constraints upon financial institution competition have created inefficiencies inimical to the public interest. However, resort to competition is justified not merely because it is efficient, but because it is believed that competition among financial institutions for loanable funds will reduce the disintermediation currently occurring in the home mortgage market. It is doubtful whether competition alone will achieve a more reliable infusion of funds into the home mortgage market; in fact the tendency may be for many thrift institutions, which are federally created specialists in home mortgage lending, to emulate the lending policies of commercial banks, which have historically minimized their home mortgage commitments. To be sure, the Administration has proposed a tax credit to encourage home mortgage investment, but that credit has been challenged as an insufficient inducement. The practical effect, then, of the Administration's proposal may be to favor the market efficiency principle over a commitment to home mortgage subsidization.

Further, the proposed competitive market solution must be questioned on the ground that the presence of economies of scale in banking may lead ultimately not to a competitive, but to a concentrated, market. Enough empirical data show such a possibility to warrant a careful evaluation of the competitive solution, especially as it is presented in the Administration's legislative scheme. Thrifts do not 
generally have the market power of commercial banks, yet the Administration's proposal still restricts them from competing in certain markets, such as business loans.

Moreover, the Administration's proposal fails to consider the effect the additional market power provided by bank trust departments will have upon the ability of thrift institutions to compete effectively with commercial banks. Evidence suggests that the inevitable conflicts of interest facing trust department management make commercial banks a beneficiary of additional market power denied thrifts. Any solution that seeks to create competition in banking must try to equalize competitive opportunities; to do that requires a consideration of the separation of trust departments from their commercial bank parents. Indications are that separation, rather than wall building, is the best way to ensure effective banking competition.

The Patman proposals, which have not yet reached legislative form, deal broadly with financial institution reform and seem to favor more of both competition and regulation. There is more competition proposed in that the proposals would open up the market by allowing thrifts to make business loans, and both thrifts and commercial banks to offer interest on demand deposits. Moreover, the proposals perhaps implicitly acknowledge the relevance of bank trust departments to the question of competition between commercial banks and thrifts by arguing that banks should be separated from the trust departments.

On the other hand, the Patman proposals seek to retain, and even expand, regulation of banking. A prominent suggestion is the protection of home mortgage loans by requiring a mandatory investment in that market based upon an institution's annual asset growth. This solution overcomes the potential inadequacies of the Administration's tax credit proposal, although admittedly at the cost of direct intervention into the marketplace. The proposals also recommend the formation of a single banking agency with the regulatory powers of the existing three banking agencies. Undoubtedly this new agency will develop an expanded regulatory role, but the drastic changes in existing market structure suggest the appropriateness of expanded responsibility. Without this agency, even sound substantive legislation may founder in application because of existing jurisdictional entanglements.

At this stage, the most complete reform proposals are presented in the Patman package. If the Financial Institutions Act cannot be expanded in scope to include consideration of those reforms, it imposes great risk upon the banking market with potential for only limited gains. Reform in the 94th Congress should demand more. 


\section{The Yale Law Journal}

Volume 83, Number 7, June 1974

\author{
Randall K. C. KaU \\ Editor-in-Chief
}

JAMES N. GARDNER

Russell K. Osgood JOAN G. WEXLER Article Editors

Paul G. Abrams

Samiel A. Alito R. Hale Andrews, Jr. Ned T. Ashby W. Duane Benton Philip C. Bobbitt JOHN R. BoltoN II RoY L. Brooks Dominic J. Campisi ANDREW H. COHN LAURA J. CorWIN SANFORd B. FERGUSON William A. Fletcher John S. Graham III Marc E. Hammond Henry B. Hansmann STEPHEN T. Holzer Holly E. Kendig Richard B. LEvin
Carl E. Anduri, Jr. Peter M. Hoffman Richard G. LINQUANTI Samuel T. Perkins MARK L. WEISSLER Note \& Comment Editors

MARK I. LEVY WALlace D. LoH WaLter P. Loughlin Alan B. LoughnaN OWEN E. MACBRIDE S. Wyatt McCallie Kathleen P. March David A. Martin Charles Mulaney, Jr. Robert M. Smith Stephen R. Mysliwiec Lewis T. Stevens Charles A. Patrizia Jan-ANDERs Paulsson John H. Peters William R. Phelps GEORGE K. RAHDERT JEFFREY E. ROCKWELL Davio B. RoE
JAMES R. SMoot Executive Editor

Williari J. Perlstein Managing Editor. REED E. HuNDT Book Review Editor

Gerald RokofF Stewart G. Rosenblum JAN SGHNEIDER Hilary S. Schultz JOHN T. SEFTON Mary A. Siegel ARThur J. Silverstein Gary J. Simson Peter W. Sly Lewis T. STEVENS Michael L. Tabak Timothy P. Terrell Dale E. Thomas Frank G. WASHINGTON REEVES C. Westbrook JOHN P. WHEELER III EDWARD A. ZELINSKY

Business Secretaries M. Olive Butrerfield, Pamela WrllatotT

\section{Student Contributors to This Issue}

R. Hale Andrews, Jr., and Andrew H. Cohn, Ungovernability: The Unjustifiable Jurisdiction

Lewis T. Stevens, Class Actions Under the Truth in Lending Act

John T. Sefton, Government Access to Bank Records

Reeves C. Westbrook, Mutual Funds and Their Advisers: Strengthening Disclosure and Shareholder Control

Hilary S. Schultz, Investing Dirty Money: Section 1962(a) of the Organized Crime Control Act of 1970 